\title{
Canada, the United Nations Human Rights Council, and Universal Periodic Review
}

\section{Joanna Harrington ${ }^{\star}$}

\section{Introduction}

In 2006, a new United Nations (UN) Human Rights Council came into existence, replacing the former UN Commission on Human Rights with a restructured body for the promotion of fundamental rights and freedoms. Heralded as a turning point for human rights within the UN system, the new forty-seven-member Council is intended to operate with a renewed emphasis on fairness, objectivity, and transparency. To help achieve these goals, the Council has developed a new mechanism for monitoring the human rights performance of all states, which it has labeled Universal Periodic Review or simply UPR. In essence, UPR is a form of performance review for states, conducted by other states, using an agreed set of standards to be universally applied with equal force. Under UPR, the human rights record of all 192 states in the world will be reviewed and assessed every four years through a process of written reports and interstate dialogue that examines a state's domestic human rights law and policies, including its constitutional protections. Canada underwent its first UPR review in February 2009, while serving as a member of the Council from 2006-09. The aim of this article is to provide an assessment of the UPR mechanism through an examination of Canada's recent experience. An overview of the Council's creation in 2006 will also be provided, as well as the details of the Council's mandate and functions, including the rules governing the UPR process.

\section{The Creation and Mandate of the Human Rights Council}

The Human Rights Council was created by the UN General Assembly through the adoption of a resolution on 15 March 2006, ${ }^{1}$ which left the details of its functions and procedures to be negotiated during the Council's first year of operation. According to this resolution, the Council was created to serve as an intergovernmental body responsible "for promoting universal respect for the protection of all human rights and fundamental freedoms for all, without distinction of any kind and in a fair and equal manner." 2 The Council was also directed to address situations of violations of human rights, including gross and systematic violations, through the adoption of recommendations, and was tasked with promoting the effective coordination and mainstreaming of human rights within the UN system. ${ }^{3}$ The Assembly also required the Council to be guided in its work by the "principles of universality, impartiality, objectivity and nonselectivity, constructive international dialogue and cooperation ..."4

In creating the Council, the Assembly also abolished the sixty-year-old Commission on Human Rights, which, despite its successes in standard setting and the generation of new conceptual understandings of human rights, ${ }^{5}$ had become a discredited talking shop, much criticized for its politicization, double standards, and selectivity, and whose membership at times allowed "the foxes to guard the henhouse." ${ }^{\text {O }}$ Of course there are contrary views, with Professor 
Marc Bossuyt of the University of Antwerp describing the politicization criticism as one:

based on a (widespread) misconception: the principal UN human rights organ is not a tribunal of impartial judges, not an academy of specialists in human rights, nor a club of human rights activists. It is a political organ composed of States represented by governments that as such reflect the political forces of the world as it is. ${ }^{7}$

Nevertheless, the text of the Assembly's resolution clearly indicates a desire to strengthen and improve the human rights machinery of the UN by recognizing "the need to preserve and build on [the Commission's] achievements and achievements and to redress its shortcomings." As Professor Nico Schrijver of the University of Leiden has observed: "Institutionally it is the first time that a UN body has been dismantled and replaced in order to achieve greater effectiveness."

The creation of the Council also constitutes a key component of the larger project of UN reform that was endorsed by states at the World Summit held in September 2005..$^{10}$ For some, the hope had been to create a Human Rights "Council" with a standing comparable to that of the UN's Economic and Social Council and the Security Council. This proposal found support in the report by the independent "High Level Panel on Threats, Challenges and Change" issued in December 2004, ${ }^{11}$ and from the UN's top civil servant at the time, UN SecretaryGeneral Kofi Annan, who was of the view that:

we need to restore the balance, with three Councils covering respectively, (a) international peace and security, (b) economic and social issues, and (c) human rights, the promotion of which has been one of the purposes of the [UN] Organization from its beginnings but now clearly requires more effective operational structures. These Councils together should have the task of driving forward the agenda that emerges from summit and other conferences of Member States, and should be the global forms (sic.) in which the issues of security, development and justice can be properly addressed. The first two Councils, of course, already exist but need to be strengthened. The third requires a far-reaching over- haul and upgrading of our existing human rights machinery. ${ }^{12}$

But to achieve such a change in legal terms would require an amendment to the UN's constitutive treaty, the 1945 Charter of the United Nations, ${ }^{13}$ which in turn would require the agreement of all states parties. Pragmatism thus led to the creation of the Council by resolution, with the new Council becoming a subsidiary organ of the General Assembly, albeit with an agreement embedded within the resolution "to review the status of the Council within five years." 14

In practical terms, however, the new Council has gained an elevation in institutional standing as a subsidiary body of the General Assembly, since the former Commission on Human Rights was one of nine commissions created by and reporting to the fifty-four-member Economic and Social Council, which in turn reports to the Assembly. The new Council is also designed to meet more frequently than the former Commission, with a minimum of three sessions per year, ${ }^{15}$ thus serving more like a standing body on human rights than a yearly get-together of government officials and human rights activists. ${ }^{16}$ In an attempt to address concerns of past politicization, the General Assembly has directed that all "members elected to the Council shall uphold the highest standards in the promotion and protection of human rights" while also providing for the possible suspension of Council members that commit gross and systematic violations of human rights by way of an Assembly vote. ${ }^{17}$ Admittedly, proposals for more robust criteria for membership have not received sufficient state support, ${ }^{18}$ and for some, the membership of China, Cuba, and Saudi Arabia alongside Canada on the Council during the formative years of 2006-09 illustrates the weak nature of the Assembly's exhortations. Nevertheless, while the potential exists for the Council to serve as nothing more than "old wine in new bottles," 19 the use of the "Council" label was intended to mark a break from the past and a desire to engage in a more constructive international dialogue on the promotion and protection of human rights. 


\section{The Push for a Peer Review Mechanism}

During the discussions in the lead-up to the 2005 World Summit, a proposal to establish a new "peer review" function for the new Council gained some ground among state representatives, with many hoping that such a mechanism would ensure that no state would be immune from human rights-related scrutiny. This proposal also received the endorsement of then Secretary-General Annan, who expressed the view (in a report circulated to states before the Summit) that "peer review would help avoid, to the extent possible, the politicization and selectivity that are hallmarks of the Commission's existing system." ${ }^{20}$

In Annan's view, the Council "should have an explicitly defined function as a chamber of peer review" ${ }^{21}$ to assess the performance of all states in regard to all human rights commitments and obligations. This new mechanism, in Annan's estimation, "would complement, but would not replace"22 the state reporting procedures that exist pursuant to the terms of the core human rights treaties, ${ }^{23}$ but which only apply to states that choose to ratify these treaties. As Annan explained, "the latter arise from legal commitments and involve close scrutiny of law, regulations and practice" with a view to making "specific and authoritative recommendations for action," while the desired "peer review" function for the new Council would be "a process whereby States voluntarily enter into discussion regarding human rights issues in their respective countries ... based on the obligations and responsibilities to promote and protect those rights arising under the Charter, and as given expression in the Universal Declaration of Human Rights." 24

Annan was also aware that the new Council would "need to ensure that it develops a system of peer review that is fair, transparent and workable," which in turn required "agreement on the quality and quantity of information used as the reference point for the review." ${ }^{25} \mathrm{He}$ also viewed the outcome of the peer review process as one that "would help the international community better provide technical assistance and policy advice," but Annan admitted that "it would help keep elected members [of the Council] accountable for their human rights commitments." ${ }^{26}$

Yet despite Annan's involvement, the rather sparse four-paragraph mention of the proposed Council in the Outcome Document from the World Summit ${ }^{27}$ suggests that there was no agreement among states as to the Council's precise functions. By March 2006, and the adoption of a specific resolution to create the Coun$\mathrm{cil},{ }^{28}$ there was support for a new peer review function, renamed one of "periodic" review, but no decision could be reached on its specific modalities. This resulted in the General Assembly directing the Council to:

\section{Undertake a universal periodic review, based on objective and reliable information, of the fulfilment by each State of its human rights ob- ligations and commitments in a manner which ensures universality of coverage and equal treatment with respect to all States; the review shall be a cooperative mechanism, based on an interactive dialogue, with the full involvement of the country concerned and with consider- ation given to its capacity-building needs; such a mechanism shall complement and not dupli- cate the work of treaty bodies;.$^{29}$}

However, the rules governing this new "universal periodic review" function were left to be negotiated by states within the Council, and they are now found in the "institution-building package" that was eventually adopted after a year of intense behind-the-scenes negotiations. ${ }^{30}$

\section{The Council's "Institution-Building Package"}

During its first year of operation, the Council was required by the General Assembly to determine the details of its new functions, with the Council being mandated to also "assume, review and, where necessary, improve and rationalize all mandates, mechanisms, functions and responsibilities of the Commission on $\mathrm{Hu}-$ man Rights in order to maintain a system of special procedures, expert advice and a complaint procedure." ${ }^{1}$ The Council was given until June 2007 to reach agreement, resulting in the eventual adoption of a package deal termed the "institution-building package." 32 This package 
was adopted officially by the Council by consensus, but became the subject of a divisive vote when forwarded to the General Assembly for its endorsement. ${ }^{33}$ Representatives of the United States and Australia (the latter now led by a Labour Government), both not members of the Council at the time, objected to a package deal that made the situation in the occupied Palestinian territories the only human rights situation in the world to be designated a permanent item on the Council's agenda, arguing that this was in contravention of the Council's founding principles of non-selectivity and objectivity. ${ }^{34}$ Canada shared this view, having stated its criticisms in the House of Commons some six months earlier, ${ }^{35}$ and having also explained (when the resolution was before the General Assembly's Third Committee) that Canada "categorically rejected the manner in which the package had been pushed through at the fifth session [of the Council], when procedural maneuvering had taken precedence over the principles at stake, thereby doing a disservice to the Council and the causes it espoused." ${ }^{36}$ Such maneuvering had prevented Canada from calling a vote on the package before the Council. As a result, Canada (along with Australia, Israel, and the United States) has disassociated itself from the "consensus" concerning the institutionbuilding package, albeit it is within this package that one finds the main elements and details of the Council's future work program.

These elements include the retention of almost all the "special procedures" (as they are called) that were developed within the former Commission involving the use of various special rapporteurs and working groups, as well as a revised complaint procedure for gross and systematic violations. ${ }^{37}$ The institution-building package also provides for the creation of a small think tank to be known as the Human Rights Council Advisory Committee ${ }^{38}$ and also provides the content for the new UPR mechanism, which is viewed by many as the Council's most innovative reform, although academic observers have already noted that the former Commission had developed a similar "periodic reporting procedure" in the early 1960s that was eventually abolished because the reports it generated on state performance were ultimately considered to be of marginal utility. ${ }^{39}$

\section{The Ground Rules for Universal Periodic Review}

The UPR mechanism is a state-driven, "action-oriented," intergovernmental process that, according to the terms of the institution-building package, must not be "overly burdensome" nor "overly long." ${ }^{30}$ States are to be reviewed by other states and not by independent experts (however determined) in the field of human rights. The process is intended to be "cooperative" ${ }^{\text {"11 }}$ rather than confrontational; however, it is to be conducted through a working group consisting of the entire forty-seven-member Coun$\mathrm{cil}^{42}$ and thus its progress is potentially affected by other activities being undertaken by these states within the Council in terms of both time and politics. Observer states (i.e. non-Council member states) may also "participate" in the proceedings of the working group, but "other relevant stakeholders" (including human rights NGOs) may only "attend" the review (and thus neither speak nor ask questions). ${ }^{43}$ Clearly, time constraints are an issue, given the need to review all 192 UN member states over a four-year period, ${ }^{44}$ with a timetable having been established to ensure that all first reviews take place by $2011 .{ }^{45}$ A "troika" of three states, selected by the drawing of lots but with respect for the ever-important principle of geographic distribution, serves as the facilitator for each state's review within the UPR process to keep matters on track. ${ }^{46}$

In terms of content, a UPR review consists of the advance provision of documentation, followed by the holding of an "interactive dialogue" within the working group, and then the adoption of a final outcome by the Council, which may or may not include recommendations for improvement. ${ }^{47}$ The documentation consists of a national report to be prepared by the state concerned, preferably "through a broad consultation process"; ${ }^{48}$ a compilation, prepared by the Office of the High Commissioner for Human Rights (OHCHR), of the information contained in the reports of the various treaty-monitoring bodies and special rapporteurs concerning the 
country being reviewed; and any "additional, credible and reliable information provided by other relevant stakeholders" thus opening the door to information supplied by NGOs and national human rights institutions. ${ }^{49}$ The actual review takes place during a three-hour ses$\operatorname{sion}^{50}$ of the working group where the state, as represented by a delegation of government officials, is questioned by representatives of other states. A report is then prepared by the working group for the state to consider and respond to as it deems necessary, leading the Council to eventually adopt a standardized "outcome" text "consisting of a summary of the proceedings of the review process, the conclusions and/or recommendations, and the voluntary commitments of the state concerned." 51

While the pace is clearly unrelenting for the diplomats involved, the creation of the UPR mechanism is intended to send the message that no country is immune from human rights scrutiny. All countries will be subjected to this new form of periodic peer review, albeit the term "peer" is used loosely here to refer to any other state. The involvement of observer states in the working group, along with the weak qualitative requirements for Council membership (as discussed above) means that all states can be peer reviewers absent any further qualifications, with realists noting that a country such as Cuba, North Korea, or Zimbabwe is no peer of Canada on matters of human rights. In any event, the focus of the review of a state is on the national level, with one of the stated goals of UPR being to raise awareness and foster improvements "on the ground," while also serving as a means to assess a state's fulfillment of "its human rights obligations and commitments." 52 It is also hoped that the new UPR mechanism will allow for the sharing of best practices, support cooperation in the promotion of human rights, and facilitate the provision of technical assistance to states in need. ${ }^{53}$

\section{Canada's UPR Review: Consideration of Past Recommendations by UN Bodies}

Canada underwent its first UPR review in
February 2009, with the review taking place while Canada was a Council member as required by the rules found within the institution-building package. ${ }^{54}$ As also required by these rules, the OHCHR prepared a ten-page compilation of the recommendations made by the various UN treaty monitoring bodies and special rapporteurs concerning Canada, ${ }^{55}$ as well as a ten-page summary of the submissions made by various NGOs. ${ }^{56}$ These documents are accurately called "compilations" and "summaries" since no independent assessment or additional analysis is provided by the OHCHR as to the validity or practicality of the information they contain. This is not, however, the fault of the OHCHR as the rules, along with budgetary considerations, limit the role of the UN's human rights secretariat to one of compiler, notwithstanding the possibility that a special rapporteur, or an entire committee of experts, could be mistaken as to their understanding of the human rights situation "on the ground" in another country. There is also the possibility that the state concerned did not agree with the findings of the UN body, nor the recommendations made which, while non-binding, ${ }^{57}$ are nevertheless included in a seemingly neutral compilation of data that is now destined for worldwide dissemination via the internet. Diplomacy and restraint usually dissuade states from issuing line-by-line rebuttals every time a UN body issues a report, but this may have to change with the OHCHR's compilations set to gain a shelf life well beyond the UPR process.

While the OHCHR's compilation usefully collects into one document the various strands of information produced by various parts of the UN human rights machinery, thus enhancing access to this information, the compilation also reports on subject matters that need context and analysis, as well as factual verification, for such information to be of utility to a performance review. For example, the compilation duly notes the regret expressed by two treaty monitoring bodies that "domestic violence is not a criminal offence" in Canada, ${ }^{58}$ but makes no mention of the existing provisions under Canadian law that address the constituent offences. This omission of context, analysis, and verification can easily mislead a reader into thinking that Canada 
lacks any penal laws to address domestic violence, and for states so motivated, the statement provides fodder for campaigns to embarrass Canada during its UPR review. Another example of the need for context and analysis can be found in the compilation's reference to the concern expressed by one treaty monitoring body concerning the "absence of effective measures to provide civil compensation to victims of torture" 59 - a startling across-the-board statement if true, but the compilation fails to note that this specific recommendation relates to a claim for compensation made by an Iranian national for torture committed in Iran at the hands of Iranian officials. ${ }^{60}$ Canada's courts rejected this claim on the basis of the long-standing doctrine of foreign state immunity, finding that state practice worldwide had yet to modify the legal doctrine so as to oblige a cause of action in a third state. Even the expert witness hired by the plaintiff had "conceded that no country has enacted legislation to give a civil remedy for torture committed outside its jurisdiction by a foreign state" and at trial he "candidly admitted that he was advocating a position where international law was going (and, in his view, should be heading),"61 thus conceding it was not law as yet.

While the OHCHR compilation correctly highlights areas where Canada's human rights law is lacking, such as the government's reluctance to implement requests for interim measures of protection, ${ }^{62}$ and the suggestion by the Supreme Court of Canada that in an exceptional case an individual can be deported to face a risk of torture, ${ }^{63}$ the compilation also touches on matters more of policy than law, as well as matters of provincial jurisdiction, again without the benefit of context or further analysis. For example, the compilation notes that one treaty monitoring body and one special rapporteur have espoused the view that Canada should "take measures against acts negatively impacting the rights of indigenous peoples outside Canada and to explore ways to hold the corporations accountable for such violations abroad." ${ }^{64}$ However, no mention is made of the extraterritorial aspects of these recommendations, and the consequences that would flow from Canada attempting to regulate conduct taking place out- side its borders; nor is any thought given to the federalism implications of any proposed regulation by Ottawa of provincially incorporated companies and provincially regulated stock exchanges. Moreover, it should also be noted that these recommendations do not concern matters of clear obligation under human rights law, but instead reflect the advocacy efforts of scholars and NGOs designed to push human rights law beyond its present boundaries. While such advocacy can be considered a noble endeavour, and a possible input into future law-making by states, this does not excuse the UN mechanisms from leaving the impression that Canada is in breach of existing obligations of international law.

As for touching on matters of provincial jurisdiction without the benefit of analysis and context, the compilation notes that one treaty monitoring body has "recommended that Canada eliminate discrimination on the basis of religion in school funding in Ontario,"65 but makes no mention of how Ottawa should do this, given that education is constitutionally a matter of provincial responsibility. Mention is also not made of the broader context in which this issue arises, with the Supreme Court of Canada having ruled that Ontario's funding of Catholic (but not Muslim or Jewish) schools is not unconstitutional. ${ }^{66}$ Recent provincial elections in Ontario have also shown little public appetite for the achievement of equality through subsidy programs or tax breaks for schools of other religious denominations. Space constraints prevent a full listing of the positive and negative aspects of the OHCHR's compilation, but as illustrated by the above examples, and frankly as required for most other forms of performance review, there is always a need for context and independent verification to ensure credibility.

\section{Information from}

\section{Nongovernmental Organizations}

As for the NGO-provided information summarized by the OHCHR, much of it reflects the particular interests of the organizations that chose to make submissions, with the content of each submission duly recorded without 
reference to any competing views or independent assessment. Thus the OHCHR's summary reveals, for example, that the Canadian HIV/ AIDS Legal Network has complained that Canada's "access to medicines regime" was "unnecessarily complex and cumbersome," while Reporters Without Borders has complained of "an increase in incidents where courts override the confidentiality of sources." ${ }^{167}$ However, this process does not encourage any nongovernment defenders of Canada's human rights record to provide their views, nor does it seek rebuttal information on specific issues. Matters of politics also arise within the NGO submissions, with Canada's decision to vote against the adoption of a United Nations Declaration on the Rights of Indigenous Peoples in September $2007^{68}$ being a predictable subject of comment, with several NGOs also lobbying for the declaration's "implementation" in Canada, ${ }^{69}$ albeit that implementation is an odd term to use for a non-legally binding, political text that is not a treaty. ${ }^{70}$ Ironically, some NGOs also criticized the special rapporteur working on matters of concern to indigenous peoples for deciding it was inappropriate to promote the implementation of the declaration with respect to Canada because Canada had voted against its adoption. ${ }^{71}$

Of the forty-nine organizations that contributed information for Canada's UPR review, only fourteen held "consultative status" with the UN's Economic and Social Council, with such status serving as a rough measure of an NGO's permanence, accountability, and general bona fides, albeit not a guarantee. The system of accreditation is not perfect. Nevertheless, to gain consultative status an NGO must be officially registered as such with the appropriate government authorities for at least two years, must have an established headquarters, a democratically adopted constitution, the authority to speak for its members, a representative structure, appropriate mechanisms of accountability, and democratic and transparent decision-making processes. ${ }^{72}$ And yet, for the purposes of reviewing a state's human rights performance within the UPR process, any unaccredited "Tom, Dick or Harry" can make a submission, which is then duly summarized by the OHCHR without further analysis or verifi- cation and published on the internet. The contrast with the limitations placed on using information provided by nonregistered associations in domestic court proceedings, and the use of expert witnesses, is stark.

It also appears that few, if any, of the organizations that submitted information for Canada's review were in a position, either by way of orientation or institutional expertise, to provide an overall assessment of Canada's human rights record. The Canadian Human Rights Commission (CHRC) did make a submission, but notwithstanding its name, the work of the CHRC is focused on matters of discrimination and equality, and not all human rights. ${ }^{73}$ The Commission has a limited statutory mandate to comment on the entire range of Canada's international human rights obligations, which extend from prison conditions to housing rights, to free speech and freedom of assembly, the right to life, and the rights of $\mathrm{Ab}$ original peoples, absent a discrimination lens through which to view the full variety of human rights. ${ }^{74}$ Of course, the CHRC may engage in consultations to enhance its knowledge base, and according to its 2008 Annual Report to Parliament: "In developing its submission, the Commission carried out extensive research and consulted with all provincial and territorial human rights commissions in the country, as well as over 60 Non-Governmental Organizations ... facilitated through the Canadian International Human Rights Network, established by Rights and Democracy." ${ }^{25}$ But one may well ask why the CHRC did not mention consultation with academics who teach and research within the full breadth of the field of human rights, and whose terms of employment ensure their independence from both government and advocacy organizations.

Nevertheless, the CHRC did make a submission for Canada's UPR review, with the OHCHR's summary indicating that the CHRC praised Canada for its recognition of the rights of gays and lesbians, including the legal recognition of same-sex marriages, ${ }^{76}$ placing Canada in opposition to the views of one UN treaty monitoring body, which has found a state's refusal to recognize same-sex marriages as being 
permissible under international human rights law. ${ }^{77}$ Canada can, of course, go further domestically than the minimum requirements of international law, and can also choose to disagree with the declaratory views of a treaty monitoring body. As for other matters mentioned by the CHRC in its submission, those included in the summary all relate to the situation of Canada's Aboriginal peoples, with the CHRC expressing "regret" with respect to Canada's position on the adoption of the Indigenous Rights Declaration. ${ }^{78}$ The CHRC had previously expressed such "regret" in its 2007 Annual Report to Parliament, ${ }^{79}$ although no mention is made of this comment being the result of a recommendation, suggestion or request as required by the CHRC's governing statute.$^{80}$ Nor does the CHRC adequately explain how what it describes as a "not legally binding" text can address matters of discrimination in Canada. ${ }^{81}$ Nevertheless, the CHRC clearly has a view that it has chosen to express, and not just to Parliament, but also to the UN and the world. Others, of course, may have a different view, with the Toronto Star having opined that Canada was right to vote against the declaration, because of its significant flaws and "fuzzy wording and overly broad guarantees." 82

In addition to these views from others, another voice missing from the nongovernmental inputs into Canada's UPR review is that of academics, with only one academic having made a submission concerning Canada's review, albeit with a specific focus. ${ }^{83}$ Many academics, however, may not be aware of the UPR process, nor of Canada's review within it, and if aware, may not be willing to participate under the guise of a "relevant stakeholder" rather than as an independent assessor or scientific observer. Of course, it does not help that the Canadian government does not engage with academics in general with respect to its international human rights activities, and to my knowledge, does not issue invitations to those within Canada's postsecondary community who teach, research, and write about human rights to its consultation sessions with civil society (although some academics may gain entry by associating with an invited NGO). ${ }^{84}$ Truly independent academic researchers, however, operate with the benefit of autonomy and freedom from instruction, and a professional commitment to methods of analysis based on evidence and objectivity. Their work could be a useful source of information for assessing Canada's human rights record, whether positive or negative, with modern technologies making it easy for governments (and for that matter, human rights commissions and parliamentary committees) to engage in consultations beyond the confines of the Toronto-Ottawa-Montreal corridor. It is also fairly easy for anyone to skim the websites of Canada's university faculties of business and law, and departments of sociology, history, and political science, to build a database of academic contacts with a variety of interests in the field of human rights, and advance planning would allow for notices to be sent to scholarly associations for distribution to their members.

\section{Canada's National Report}

In addition to the documentation prepared by the OHCHR, Canada also submitted a twenty-one page national report, which was said to be "prepared in collaboration by the federal, provincial and territorial governments in Canada" 85 but apparently without the "broader process of consultation" desired by the rules. ${ }^{86}$ The report reveals that Canadian government officials did consult with "Canadian civil society" (whoever that might include) at a workshop held in June 2008, and later posted information on its website inviting civil society to submit questions and comments. ${ }^{87}$ There is, however, no information suggesting that this invitation to participate was actively drawn to the attention of university researchers, lawyers, provincial Law Societies and local Bar associations, chambers of commerce and business associations, and the general public, and at least one parliamentary committee has already concluded that "the processes and procedures used for Canada's first UPR, both at the [Council] and at the domestic levels, lacked clarity and transparency." ${ }^{8}$ This committee has also urged the Canadian government to develop a "clear, effective and transparent plan for Canada's next UPR" with the hope that such a plan "could establish broad and meaningful consultation and 
engagement with relevant stakeholders, parliamentarians and the Canadian public during the time period leading up to the next UPR." ${ }^{9}$

In any event, Canada's national report was submitted to the OHCHR approximately one month before Canada's scheduled dialogue session in Geneva. With respect to content, Canada used its report to explain the significance of its federal structure as well as its existing arrangements for the protection and promotion of its human rights obligations, emphasizing quite correctly that Canada can implement these obligations through a combination of laws, regulations, policies, and programs at the federal, provincial, and territorial levels. ${ }^{90}$ Canada also stated which human rights treaties it was currently considering for future ratification, and thus indicated which treaties it was not considering regardless of the encouragements expressed in the past by various UN treaty monitoring bodies. ${ }^{91}$ Canada also identified issues likely to be discussed during its review, tackling head-on challenges arising with respect to Canada's record concerning the rights of Aboriginal peoples, poverty reduction, homelessness, violence against women, and issues of racism arising within the context of immigration, and national security.

\section{Canada's Dialogic Review within the Working Group}

A month later, on 3 February 2009, the "interactive dialogue" concerning Canada's human rights record took place within the "Working Group on the Universal Periodic Review," facilitated by a troika of diplomats from the United Kingdom, Azerbaijan, and Bangladesh. During the three-hour session, Canada was represented by a delegation of nineteen civil servants, with nine having been sent to Geneva from Ottawa at the taxpayers' expense, and three having come from the provincial civil services of Saskatchewan and Québec. ${ }^{92}$ Predictably, Canada was asked to reconsider its position with respect to the Indigenous Rights Declaration, and was asked by several states why it did not criminalize domestic violence (!). Some states even repeated this question after Canada had responded oral- ly at its first opportunity to correct the record, ${ }^{93}$ suggesting that this "dialogue" is more an opportunity for diplomats to deliver pre-prepared statements in the order of a speaker's list than a true opportunity for information gathering. The statements made at the UPR dialogue cover a wide range of topics and reveal no general themes, nor do they reveal a focused inquiry. Canada was asked, for example, to ratify more treaties, including the American Convention on Human Rights ${ }^{94}$ (a regional treaty and thus beyond the scope of the UPR's mandate), while Canada was also asked (rightly in my view) to improve its consultation processes in preparing for its UPR review. ${ }^{95}$ Canada also faced questions about allegations of racial profiling and discrimination against members of the Arab and Muslim community, as well as questions about its use of national security certificates, alongside questions about poverty reduction, socioeconomic disparities, and homelessness. Canada's voting record within the Council ${ }^{96}$ was also a factor at its UPR review, with Cuba asking why Canada was no longer "an advocate for the third world" and Algeria, Syria, and Iran criticizing Canada's "double standards and politicization" within the Council, presumably in reference to Canada's opposition to a series of Council resolutions focusing on Israeli actions in the occupied territories. Canada was also asked about its change of policy on seeking clemency for Canadians facing the death penalty abroad, ${ }^{97}$ an issue that had been in the news and in the domestic courts, ${ }^{98}$ but which received no comment in any of the advance documentation provided by the OHCHR, nor in the national report provided by Canada.

After the dialogue, Canada received a report prepared by the working group summarizing the comments made by its peer reviewers and providing a list of the sixty-eight recommendations that had been made during the session. ${ }^{99}$ Canada responded publicly to these recommendations in early June 2009, posting its response on the website of the Department of Canadian Heritage. ${ }^{100}$ Given the wording of some of the recommendations, which can easily mix agreeable platitudes with content of concern, it is not easy to state categorically that Canada has either accepted or rejected all sixty-eight rec- 
ommendations. A more nuanced count would suggest that Canada has accepted twenty-six recommendations, has accepted in part fourteen recommendations, has accepted the underlying principle of eight recommendations, but has rejected outright fifteen recommendations. The remaining five recommendations concern matters that are already in place. Having given a response to the recommendations, a decision on the final outcome of Canada's UPR review was adopted by the Council's plenary on 9 June 2009, using the standard form and without a vote. ${ }^{101}$ Questions remain, however, as to the usefulness of this review and whether Canada's progress in meeting the recommendations with which it has agreed will be monitored through a credible process at either the national or international level. There is also a question as to whether anyone, apart from the government officials involved and several human rights NGOs, will even follow the results of Canada's review, given the lack of effective mechanisms to engage a broader segment of society in consultation, raising in turn the question of whether the new UPR mechanism, as currently constituted, can truly serve as a catalyst for stimulating a national process of self-examination, scrutiny, and effective review.

\section{Conclusions}

While the UPR mechanism is often touted as the main innovation of the new Human Rights Council, its state-driven structure does not bar political considerations from arising, and allied states are clearly free to work together on either a concerted campaign of "gotcha" aimed at one state or another, or as a mutual praise society to assist each other's review. In establishing the UPR mechanism, it was hoped that the process would provide needed information concerning the situation of human rights "on the ground" to enable states to draw on the experience of others for inspiration and guidance. It was also hoped that each UPR review might stimulate an authentic national dialogue within each state, and either raise awareness or supplement existing efforts to "name and shame" those states deserving criticism for their human rights record. On the other hand, a UPR review could also simply serve as a mask for accountability, giving the appearance that a state is taking action to ensure the implementation of its obligations. Clearly, for the UPR process to become truly innovative (and distinct from its past incarnation before the former Commission), there needs to be greater opportunities for the use of truly independent appraisals of a state's human rights performance, and not simply the cut-and-paste summation of treaty body recommendations and information supplied by advocacy groups. States such as Canada could, however, assist with this desire for expert information and independent assessment by expanding the consultation circle. Parliamentary committees could review the recommendations made by UN bodies when they are first made, making use of the relevant testimony of various experts during their inquiries. The reports produced by these parliamentary committees could then be used in the preparation of Canada's next national report, providing a means to respond to any inaccurate or inappropriate recommendations long before such recommendations are repeated in a submission for a UPR review. And yet, in the final analysis, it may be expecting too much of a UN intergovernmental body which, despite laying claim to the evocative label of "human rights," remains a political body subject to the political machinations of states wanting to achieve very different political goals. One may also have to ask, perhaps in preparation for the Council's planned review in 2011, whether a state-controlled body tasked with reviewing the human rights record of its peers has the necessary institutional structure to serve as a credible voice for ensuring the implementation and enforcement of existing human rights obligations, with national bodies - including government, Parliament, and the courts - being the more likely conduits for concrete action.

\section{Notes}

* $\quad$ B.A. (UBC), LL.B. (UVIC), Ph.D. (Cambridge); Professor of Law at the University of Alberta and past Scholar-in-Residence with the Legal Affairs Bureau of the Government of Canada's Department of Foreign Affairs and International Trade from 2006-08. The views expressed in this article are those of the author and should not be attrib- 
uted to the Government of Canada.

1 Human Rights Council, GA Res. 60/251, UN

GAOR, 60th Sess., Supp. No. 49 (Vol. III) at 2-5, UN Doc. A/RES/60/251 (2006) [GA Res. 60/251], adopted by a recorded vote of 170 states in favour (including Canada), four against (Israel, Marshall Islands, Palau, and the United States), and three abstentions (Belarus, Iran, and Venezuela).

$2 \quad$ Ibid. at para. 2, repeating verbatim paragraph 157 of 2005 World Summit Outcome, GA Res. 60/1, UN GAOR, 60th Sess., Supp. No. 49 (Vol. I) at 3-25, UN Doc. A/RES/60/1 (2005) [GA Res. 60/1].

3 GA Res. 60/251, supra note 1 at para. 3, repeating verbatim GA Res. 60/1, ibid. at para. 158.

4 GA Res. 60/251, supra note 1 at para. 4.

5 See generally Philip Alston, “The Commission on Human Rights" in Philip Alston, ed., The United Nations and Human Rights: A Critical Appraisal (Oxford: Oxford University Press, 1992) at 126-210.

6 The most notorious examples being the widely reported ousting of the United States in 2001, the election of Sudan in 2002, and the Libyan chairmanship in 2003. Nongovernmental organizations (NGOs) certainly viewed the questionable human rights records of some members of the Commission as a central handicap: Nazila Ghanea, "From UN Commission on Human Rights to UN Human Rights Council: One Step Forwards or Two Steps Sideways?” (2006) 55 International and Comparative Law Quarterly 695 at 699. See also Philip Alston, "Reconceiving the UN Human Rights Regime: Challenges Confronting the New UN Human Rights Council” (2006) 7 Melbourne Journal of International Law 185 at 191-92.

7 Marc Bossuyt, “The New Human Rights Council: A First Appraisal” (2006) 24:4 Netherlands Quarterly of Human Rights 551 at 554.

8 GA Res. 60/251, supra note 1 , preamble at para. 8 [emphasis added].

9 Nico Schrijver, “The UN Human Rights Council: A New "Society of the Committed" or Just Old Wine in New Bottles?" (2007) 20 Leiden Journal of International Law 809 at 822.

10 See further, GA Res. 60/1, supra note 2 at paras. 157-60. See also In Larger Freedom: Towards Development, Security and Human Rights for All: Report of the Secretary-General, UN Doc. A/59/2005 (2005) [In Larger Freedom], especially paras. 140-47 and 181-83.

11 See further, A More Secure World: Our Shared Responsibility: Report of the High Level Panel on Threats, Challenges and Change (Chair: Anand Panyarachun), UN Doc. A/59/565 (2004) at para.
291.

12 In Larger Freedom, supra note 10 at para. 166.

1326 June 1945, Can. T.S. 1945 No. 7 (entered into force 24 October 1945) [UN Charter].

14 GA Res. 60/251, supra note 1 at paras. 1 and 16.

15 Ibid. at para. 9.

16 The Commission had met annually in Geneva for one hectic six-week session attended by over 3000 people.

17 GA Res. 60/251, supra note 1 at para. 9.

18 On the membership criteria debate, see Philip Alston, "Richard Lillich Memorial Lecture: Promoting the Accountability of Members of the New UN Human Rights Council” (2005) 15:1 Journal of Transnational Law \& Policy 49. See also Alston, "Reconceiving the UN Human Rights Regime," supra note 6 at 188-204.

19 See Schrijver, supra note 9.

20 In Larger Freedom: Towards Development, Security and Human Rights for All: Report of the SecretaryGeneral: Addendum: Human Rights Council, UN Doc. A/59/2005/Add.1 (2005) [In Larger Freedom (Addendum)] at para. 8 .

21 Ibid. at para. 6.

22 Ibid. at para. 7.

23 The details of the eight treaty-monitoring bodies and the procedures requiring states to report periodically on their treaty implementation efforts can be found online at <http:/www2.ohchr.org/ english/bodies/treaty/index.htm $>$. Canada currently reports to all but two of the eight bodies, since Canada is a party neither to the International Convention on the Protection of the Rights of All Migrant Workers and Members of Their Families, 18 December 1990, 2220 U.N.T.S. 3, (1991) 30 I.L.M. 1521 (entered into force 1 July 2003), nor the Convention on the Rights of Persons with Disabilities, 13 December 2006, GA Res. 61/106, UN GAOR, 61st Sess., Supp. 49 (Vol. I) at 65-82, UN Doc. A/RES/61/106 (2006), (2007) 46 I.L.M. 443 (entered into force 3 May 2008). Canada, among others, does not consider the Migrants Workers Convention to be a "core" convention, at least at present, given its relatively low level of ratification. Canada is a signatory, but not yet a party, to the Disability Rights Convention.

24 In Larger Freedom (Addendum), supra note 20 at para. 7.

25 Ibid. at para. 8.

26 Ibid.

27 GA Res. 60/1, supra note 2.

28 GA Res. 60/251, supra note 1.

29 Ibid. at para. 5(e).

30 And later clarified by way of a President's State- 
ment issued by the Council: see Modalities and practices for the universal periodic review process, Human Rights Council President's Statement 8/1 of 9 April 2008, reprinted in Report of the Human Rights Council, UN GAOR, 63d Sess., Supp. No. 53 at 237-9, UN Doc. A/63/53 (2008).

31 GA Res. 60/251, supra note 1 at para. 6.

32 Institution-building of the United Nations Human Rights Council, Human Rights Council resolution 5/1 of 18 June 2007, [HRC Res. 5/1] reprinted in Report of the Human Rights Council, UN GAOR, 62d Sess., Supp. No. 53 at 48-73, UN Doc. A/62/53 (2007). For a fuller discussion of both the text's adoption and its content, see Claire Callejon, "Developments at the Human Rights Council in 2007: A Reflection of its Ambivalence" (2008) 8:2 Human Rights Law Review 323.

33 See Report of the Human Rights Council, GA Res. 62/219, UN GAOR, 62d Sess., Supp. No. 49 (Vol. I) at 434-435, UN Doc. A/RES/62/219 (2007) [GA Res. 62/219], adopted by a recorded vote of 150 to 7 (Australia, Canada, Israel, Marshall Islands, Micronesia, Palau, and the United States), with 1 abstention (Nauru).

34 As recorded in UN GAOR, 62d Sess., 79th Plen. Mtg., UN Doc. A/62/PV.79 (2007) at 10-11.

Academic observers have also noted that while the human rights situation in the occupied territories should be addressed, it is unfortunate that a specific agenda item be dedicated to it and not to other human rights situations: Callejon, supra note 32 at $337-38$.

35 When questioned in the House of Commons on why Canada did not agree with the institutionbuilding package, the Hon. Peter MacKay, then Minister of Foreign Affairs, explained that: "We cannot, for expedience, accept a permanent agenda item on the Palestinian territories, singling out one situation while at the same time eliminating a special human rights scrutiny of countries of concern, such as Cuba and Belarus. It is a contradiction [with the Council's founding principles] ...": House of Commons Debates, vol. 141, no. 175 (20 June 2007) at 10900. UN GAOR, 62d Sess., Third Committee, 47th Mtg., UN Doc. A/C.3/62/SR.47 (2007) at para. 35. HRC Res. 5/1, supra note 32, Annex, Part IV at paras. 85-109. Since 1967 the former Commission had examined information relevant to gross violations of human rights in specific country situations, and since 1970 it had also examined communications that appeared to reveal a consistent pattern of gross and reliably attested violations. The latter become known as the confidential "1503 procedure," so named after the resolution number by which it was created. See further, Nigel S. Rodley \& David Weissbrodt, "United Nations Nontreaty Procedures for Dealing with Human Rights Violations" in Hurst Hannum, ed., Guide to International Human Rights Practice, 4th ed. (Ardsley, NY: Transnational, 2004) at 65-74. See also Alston, "The Commission on Human Rights," supra note 5 at 145-55 (who views the 1503 procedure as deeply flawed), and Callejon, supra note 32 at 332 (who notes that the procedure was of more use in the 1970s and 80s when fewer states had ratified the treaty-based complaint procedures).

38 HRC Res. 5/1, ibid., Annex, Part III at paras. 65-84.

39 See Bossuyt, supra note 7 at 553 , fn 12 , and for a full discussion, see Alston, "Reconceiving the UN Human Rights Regime," supra note 6 at 207-13.

40 HRC Res. 5/1, supra note 32, Annex, Part I at paras. 3(h), 3(i) and $3(\mathrm{~b})$ respectively.

41 Ibid. at para. 3(b).

42 Ibid. at para. 18(a).

43 Ibid. at paras. 18(b)-(c). In June 2008, the Council agreed to permit NGOs to make "general comments" during the time allocated for the adoption of the final outcome decision at the Council's plenary session. There remains, however, some state resistance to this opportunity for NGO participation: Marianne Lilliebjerg, "The Universal Periodic Review of the UN Human Rights Council - An NGO Perspective on Opportunities and Shortcomings" (2008) 26:3 Netherlands Quarterly of Human Rights 311 at 314.

44 HRC Res. 5/1, supra note 32, Annex, Part I at para. 14.

45 The schedule is available online at $<\mathrm{http}: / / \mathrm{www}$. ohchr.org/EN/HRBodies/UPR/Documents/uprlist.pdf $>$.

46 HRC Res. 5/1, supra note 32, Annex, Part I at para. 20.

47 All documents are available from the dedicated website on UPR maintained by the Office of the UN High Commissioner for Human Rights (OHCHR) at: <http://www.ohchr.org/EN/HRBodies/UPR/Pages/UPRMain.aspx $>$. A somewhat duplicative site, maintained by a presumably wellintentioned but specifically-created NGO, can be found at: <http://www.upr-info.org/>.

48 General guidelines on the preparation of national reports were adopted by the Council in September 2007. See Human Rights Council decision 6/102 of 27 September 2007, reprinted in Report of the Human Rights Council, UN GAOR, 63d Sess., Supp. No. 53 at 75, UN Doc. A/63/53 (2007). 
HRC Res. 5/1, supra note 32, Annex, Part I at para. 15 (“Documentation”).

As

Ibid. at para. 22.

Ibid. at para. 26.

Ibid. at para. 4.

Ibid. at paras. 4(c)-(f).

Ibid. at para. 8.

Compilation Prepared by the Office of the High

Commissioner for Human Rights, in accordance with paragraph 15(b) of the Annex to Human Rights Council Resolution 5/1: Canada, UN Doc. A/HRC/WG.6/4/CAN/2 (17 December 2008) [OHCHR Compilation for Canada].

Summary Prepared by the Office of the High Commissioner for Human Rights, in accordance with paragraph 15(c) of the Annex to Human Rights Council Resolution 5/1: Canada, UN Doc. A/ HRC/WG.6/4/CAN/3 (24 December 2008) [OHCHR Summary of NGO Information for Canada]. It is often forgotten, or overlooked, that the concluding observations made by UN treaty monitoring bodies are recommendatory in nature and not legally binding, with Canada's own Standing Senate Committee on Human Rights oddly noting that: "Strict compliance with UN treaty body recommendations is often lacking" and calling on Canada to "live up to its reputation by implementing and complying with such recommendations": Standing Senate Committee on Human Rights, Canada and the United Nations Human Rights Council: At the Crossroads: Interim Report (Chair: Raynell Andreychuk) (May 2007) at 53. Why is "strict compliance" necessary for a recommendation? The Committee even includes mention in its report (at 15), citing the testimony of the Canadian head of Amnesty International, that some treaty body members "are not independent and do not possess the required expertise".

OHCHR Compilation for Canada, supra note 55 at para. 15.

Ibid. at para. 21.

Bouzari v. Iran (Islamic Republic), [2002] O.J. No. 1624, (S.C.J.); affirmed on appeal, [2004] 71 O.R. (3d) 675 (C.A.). For commentary, see Francois Larocque, "Bouzari v. Iran: Testing the Limits of State Immunity in Canadian Courts" [2003] 41 Canadian Yearbook of International Law 343.

As held by Justice Swinton in Bouzari v. Iran (Islamic Republic), [2002] O.J. No. 1624 (S.C.J.) at paras. 46 and 52, in comparing the expert opinion evidence of Professor Ed Morgan of the University of Toronto, who appeared on behalf of the plaintiff, with that of Professor Christopher Greenwood QC of the London School of Economics, now H.E. Judge Greenwood of the
International Court of Justice, who appeared on behalf of the intervenor, the Attorney General of Canada.

62 OHCHR Compilation for Canada, supra note 55 at para. 8. See further, Joanna Harrington, "Punting Terrorists, Assassins and Other Undesirables: Canada, the Human Rights Committee and Requests for Interim Measures of Protection" (2003) 48 McGill Law Journal 55.

63 Ibid. at para. 22, with reference to Suresh $v$. Canada, [2002] 1 S.C.R. 3. See further, Joanna Harrington, “The Role for Human Rights Obligations in Canadian Extradition Law” [2005] 43 Canadian Yearbook of International Law 45 at 94.

64 OHCHR Compilation for Canada, supra note 55 at para. 45.

65 Ibid. at para. 25 referring to the case of Waldman v. Canada, Communication No. 694/1996, UN Doc. CCPR/C/67/D/694/1996 (views adopted 3 November 1999), reprinted in Report of the Human Rights Committee, UN GAOR, 55th Sess., Supp. No. 40, UN Doc. A/55/40, vol. II, annex IX.H (finding Canada in violation of its international human rights obligations).

66 See Adler v. Ontario, [1996] 3 S.C.R. 609.

67 OHCHR Summary of NGO Information for Canada, supra note 56 at paras. 7 and 30 .

68 The declaration text is found in the annex to United Nations Declaration on the Rights of Indigenous Peoples, GA Res. 61/295, UN GAOR, 61 ${ }^{\text {st }}$ Sess., Supp. No. 49 (Vol. III) at 15-25, UN Doc. A/ RES/61/295 (2007), adopted by a recorded vote of 143 in favour, 4 against (Australia, Canada, New Zealand, and the United States), with 11 abstentions.

69 OHCHR Summary of NGO Information for Canada, supra note 56 at paras. 5 and 58, and implied in para. 57.

70 Canadian law speaks of the implementation of a ratified human rights treaty, with ratification being an indication of a state's expression of consent, and the interpretive use of the values of an unimplemented but ratified treaty: see Baker v. Canada (Minister of Citizenship and Immigration), [1999] 2 S.C.R. 817 at paras. 69-71.

71 OHCHR Summary of NGO Information for Canada, supra note 56 at para. 16.

72 See Consultative relationship between the United Nations and non-governmental organizations, ESC Res. 1996/31, UN ESCOR, Sess. 1996, Supp. No. 1 at 53-61, UN Doc. E/1996/96 (1997).

73 Section 2 of the Canadian Human Rights Act, R.S.C., c. H-6, explains that the "Purpose of the Act" is to give effect to the principle that all individuals should not be hindered by discrimination. 
This principle is then referenced in section 27 of the Act concerning the CHRC's powers, duties and functions.

Pursuant to s. 27(1)(e) of the Canadian Human Rights Act, R.S.C., c. H-6, the CHRC "may consider such recommendations, suggestions and requests concerning human rights and freedoms as it receives from any source and, where deemed by the Commission to be appropriate, include in a report referred to in section 61 reference to and comment on any such recommendation, suggestion or request" [emphasis added], but this suggests that the CHRC may consider matters of human rights and freedoms, beyond matters of discrimination, but its ability to make reference to and comment on such matters should be directed to Parliament, which is the audience for a "report referred to in section 61." Under s. 27(1)(f) of the Act, the CHRC can also carry out "such studies concerning human rights and freedoms as may be referred to it by the Minister of Justice", which also illustrates that with respect to matters of human rights and freedoms, as distinct from matters of discrimination and equality, Parliament has placed limits on the CHRC's mandate. Yet, despite these limitations, the CHRC serves internationally as the chair of the International Coordinating Committee of National Institutions for the Promotion and Protection of Human Rights. Canadian Human Rights Commission, 2008 Annual Report (Ottawa: Minister of Public Works and Government Services, 2009) at 10. "Rights \& Democracy" is the nom de plume of the corporation known as the "International Centre for $\mathrm{Hu}$ man Rights and Democratic Development" that was established by Parliament to "initiate, encourage and support cooperation between Canada and other countries in the promotion, development and strengthening of democratic and human rights institutions and programs": International Centre for Human Rights and Democratic Development Act, S.C. 1985, c. 54 (4th Supp.), s. 4(1). The work of Rights \& Democracy is not focussed on tracking Canada's human rights performance. OHCHR Summary of NGO Information for Canada, supra note 56 at para. 72.

77 See Joslin v. New Zealand, Communication No. 902/1999, UN Doc. CCPR/C/75/D/902/1999 (views adopted 17 July 2002), reprinted in Report of the Human Rights Committee, UN GAOR, 57th Sess., Supp. No. 40, UN Doc. A/57/40 (2002), vol. II, annex IX.Z. OHCHR Summary of NGO Information for Canada, supra note 56 at para. 3 .
Report 2007 (Ottawa: Minister of Public Works and Government Services, 2008) at 5-6.

80 See supra note 74.

81 According to the Commission: "While the Declaration is not legally binding, it represents "a standard of achievement to be pursued in a spirit of partnership and mutual respect" (quoting, without citation, but in circular fashion, from the declaration itself): Annual Report 2007, supra note 79 at 5.

82 "Caution on native rights" The Toronto Star (17 September 2007) A6.

83 OHCHR Summary of NGO Information for Canada, supra note 56 at para. 59. The academic concerned was the Canada Research Chair in International Migration Law.

84 By contrast, the Netherlands has long made use of an independent body comprised of academics and other experts, known as the Advisory Council on International Affairs (AIV), which advises government and parliament on foreign policy matters, including issues relating to human rights, through the production of advisory reports. These reports, and government responses, are made available in several languages at: $<\mathrm{http} / /$ www.aivadvice.nl/>.

85 National Report Submitted in Accordance with Paragraph 15(a) of the Annex to the Human Rights Council Resolution 5/1: Canada, UN Doc. A/ HRC/WG.6/4/CAN/1 (5 January 2009) [National Report for Canada].

86 See supra note 48.

87 National Report for Canada, supra note 85 at para. 2.

88 Standing Senate Committee on Human Rights, Canada's Universal Periodic Review Before the United Nations Human Rights Council: Second Report (May 2009) at para. 5.

89 Ibid. at para. 6.

90 National Report for Canada, supra note 85 at paras. 8-10 and 18.

91 Ibid. at para. 20.

92 Details on the composition of the delegation are found in the annex to Report of the Working Group on the Universal Periodic Review: Canada, UN Doc. A/HRC/11/17 (3 March 2009) [UPR Working Group Report on Canada] at 24.

93 Ibid. at paras. 21 (Italy) and 29 (Mexico), para. 36 (response by Canada), and paras. 40 (Brazil), 45 (Malaysia), 47 (Turkey) and 71 (France). Domestic violence was also raised in the statements delivered by Austria (para. 20), Chile (para. 22), Czech Republic (para. 49), Saudi Arabia (para. 63), Japan (para. 67), and the Syrian Arab Republic (para. 74). 
9422 November 1969, 1144 U.N.T.S. 123, O.A.S.T.S. No. 36, (1970) 9 I.L.M. 673 (entered into force 18 July 1978).

95 UPR Working Group Report on Canada, supra note 92 at paras. 29 (Mexico) and 40 (Brazil) concerning the American Convention on Human Rights (ibid.) and resulting in recommendation 8, and para. 49 (Czech Republic) concerning consultation.

$96 I$ Ibid. at paras. 23, 27, 54, and 74, resulting in recommendations 65-68.

97 UPR Working Group Report on Canada, supra note 92 at paras. 33 (Netherlands) and 76 (Denmark).

98 See Smith v. Canada (Attorney General), 2009 FC 228 (directing the Canadian government to seek clemency for a Canadian citizen named Ronald Smith who had been convicted of murder in Montana and sentenced to death).

99 UPR Working Group Report on Canada, supra note 92 at para. 86.

100 Universal Periodic Review Response of Canada to the Recommendations, UN Doc. A/HRC/11/17/ Add.1 (8 June 2009), and made available at: $<$ http://www.pch.gc.ca/pgm/pdp-hrp/inter/101eng.cfm $>$.

101 Outcome of the Universal Periodic Review: Canada, Human Rights Council decision 11/103 of 9 June 2009, reprinted in Report of the Human Rights Council on its Eleventh Session, UN Doc. A/ $\mathrm{HRC} / 11 / 37$ at 80 . 